\title{
Standards for Evaluating the Remote Education Quality of Teaching Listening and Speaking Skills from the Perspectives of Teachers and Students
}

\author{
Dr. Ahmed Ezzat \\ City University College of Ajman, PO box 18484, UAE
}

\begin{abstract}
The research aims to prepare a list of standards necessary to measure the quality of the distance education system in teaching listening and speaking skills in the UAE, and to identify the availability of these standards in educational practices for both the teacher and the learner in teaching listening and speaking skills, as well as determining the necessary procedures to enable teachers and students to acquire these Standards in teaching listening and speaking skills.
\end{abstract}

Keywords:Standards, Evaluation, quality, Distance education, Remote education

DOI: $10.7176 / \mathrm{ADS} / 89-03$

Publication date: January $31^{\text {st }} 2021$

\section{Introduction:}

The world is witnessing at the present time a great change in various aspects and lifestyles, especially educational ones, as a result of the developments and changes brought about by the Corona pandemic, (Aarssen, L. W., \& Crimi, L. (2016). Legacy, leisure and the 'work hard-Play hard' hypothesis. The Open Psychology Journal et al., 2000)which necessitated the necessity of changing the traditional education system in schools, and applying the distance education system as an educational system with specific rules, conditions and procedures that each of The teacher and the learner(Boud et al., 2016), and in the context of the researcher's endeavor to measure the quality of the distance education system in teaching listening and speaking skills and to identify its effectiveness, The researcher sought to design an objective standard to judge the quality of the practices followed by the teacher and the learner during the application of the distance education system in teaching listening and speaking skills(Ojakaa et al., 2014), with the aim of identifying the effective procedures that must be followed in order to develop those practices and procedures followed by the teacher and the learner, and to improve the educational environment in general. And enabling the learner to develop his teaching and learning experiences(Boud et al., 2016)(Deye, N., Vincent, F., Michel, P., Ehrmann, S., Da Silva, D., Piagnerelli, M., ... Laterre, P.-F. (2016). Changes in cardiac arrest patientsâ€TM temperature management after the 2013 â€œTTMâ€ trial: Results from an international survey. Annals of Intensive et al., 2016), and enabling the teacher to achieve his academic goals and to identify the extent of achieving the learning outcomes(Mathew, R. V., \& Panchanatham, N. 2016. An exploratory study on the development of women entrepreneurs: Indian cases. Journal of Research in Marketing and Entrepreneurship et al., 2018).

\section{Problem statement:}

The learner's role in the present era was not limited to receiving knowledge and information as it was used in the traditional education system. Rather, this role has changed completely in the distance education system to become an active, active, planned and implementer role for many practices and procedures that enable him to develop his personality, and the researcher was briefed on the practices And the procedures followed by the teacher and the learner in the distance education system and found that they need further development and improvement, hence the thought of conducting a scientific study aimed at assessing the quality of the distance education system in teaching listening and speaking skills, so the researcher sought to design a standard to measure the efficiency of these practices in terms of On the other hand, assisting teachers and learners to achieve their goals in the process of studying, research and developing their personality. To address the current research problem, the following question is formed:

- How can the quality of distance education in teaching listening and speaking skills be evaluated from the viewpoint of teachers and students?

This main question is divided into the following sub-questions:

1 - What are the necessary criteria to measure the quality of the distance education system in teaching listening and speaking skills?

2- What is the availability of standards in educational practices for both the teacher and the learner in teaching listening and speaking skills?

3- What are the necessary procedures that enable teachers and students to acquire these standards in teaching listening and speaking skills? 


\section{Research importance}

The importance of the research is:

1- Helping teachers and learners by providing them with objective criteria to evaluate the educational, methodological, technical and scientific practices that are presented in the distance education system in order to improve and develop the educational environment.

2- Developing the educational evaluation system and its tools by building scientific and objective standards; To become an objective measurement tool to judge the teacher and the learner.

3- Building interactive enrichment activities that enable the learner to acquire new and developed experiences, and help the teacher achieve teaching goals.

\section{The theoretical framework of the current research}

\section{The first axis - quality (its concept, importance and objectives):}

Quality in education is defined as "a set of procedures and guidelines set by an educational institution to guide them in managing, organizing its work and providing its services, and what it requires in producing various educational materials and using multiple media and activities related to studying students' needs and evaluating the needs of the labor market in line with the educational process outcomes.

Quality derives its importance from the increasing interest in the quality of education, educational excellence, the level of quality of inputs, processes and outputs, the changes occurring internationally and locally, and as a result of the increasing intensity of competition between production and service institutions, and in light of this the increase in supply over demand, which imposed on educational institutions to improve their outputs and adopt a quality system. Shamil helps fully meet the needs of society and the beneficiaries, and uses scientific methods that contribute to curriculum development, human resource development and education technologies, as the quality of higher education is focused around two main aspects, namely, quality control and its sustainability.

\section{The second axis - distance education (its concept, advantages, and justifications for the need for it):}

Distance education is known as "a teaching style based on self-learning using modern technology with the aim of achieving perfection and working to effectively transfer educational material and direct and indirect academic interaction between the teacher and the learner and between the learners each other, bypassing temporal and spatial barriers."

Distance education is distinguished by relying on different means and multiple and different sources in communicating information to learners, making use of modern technology, and its developments in the transmission of science live and directly, and enabling the learner to communicate orally or in writing with his teachers and colleagues, and distance education enables students to acquire skills Related to the use of computers and the Internet, and the individualization of education so that there is more consideration for individual differences, and to facilitate scientific research, And expanding opportunities for admission to postgraduate studies, in addition to saving in administrative structures, relieving pressure on them, providing educational opportunities for social groups that are not absorbed by regular education, such as the handicapped and the elderly, saving time and effort on agencies and institutions related to the educational process, and choosing the elite of teachers in each specialty according to Worldwide, regardless of their place of residence, distance education also addresses some of the problems associated with higher education, such as: the problem of congestion and pressure on means of transportation, environmental pollution, and the increase in the number of students registered with the shortage of school buildings and restrictions imposed on teachers represented in administrative work and traditional roles .

\section{Research results and their interpretation:}

\section{1- Results related to the first question of the research questions:}

The text of the first question includes the following: What are the necessary criteria to measure the quality of the distance education system in teaching listening and speaking skills? The standards necessary to measure the quality of the distance education system have been determined by building a questionnaire for this purpose, as the researcher relied on building them on a study of global and national research and projects that dealt with standard levels in general and standard levels in teaching listening and speaking skills in particular, and the results of previous research and studies in The field of teaching listening and speaking skills in particular, And to verify its validity and consistency, then apply it to a group of (specialists in curricula and methods of teaching the Arabic language), and it was judged. In order to obtain the skills that are approved by $80 \%$ or more of the referees, then these skills are used in the current research tools, and the final picture of these criteria is in Appendix No. (1). 
Table No. (1) The percentages of the extent to which the criteria needed to measure the quality of the distance education system in teaching listening and speaking skills are appropriate

\begin{tabular}{|c|c|c|}
\hline SN & $\begin{array}{c}\text { Standards needed to measure the quality of the distance education system in } \\
\text { teaching listening and speaking skills }\end{array}$ & Percentage \\
\hline \multicolumn{3}{|c|}{ First - educational standards, which include: } \\
\hline 1 & $\begin{array}{l}\text { Distance education achieves positive interaction with knowledge and information } \\
\text { in teaching listening and speaking skills. }\end{array}$ & $(\% 80)$ \\
\hline 2 & $\begin{array}{l}\text { Distance education enables the teacher to achieve his educational goals in teaching } \\
\text { listening and speaking skills. }\end{array}$ & $(\% 100)$ \\
\hline 3 & $\begin{array}{l}\text { Students interact positively with the teacher and subject in teaching listening and } \\
\text { speaking skills. }\end{array}$ & $(\% 85)$ \\
\hline 4 & $\begin{array}{l}\text { Taking into account the cultural and linguistic side of the teacher and the learner } \\
\text { in teaching listening and speaking skills. }\end{array}$ & $(\% 85)$ \\
\hline 5 & $\begin{array}{l}\text { The effectiveness of students in practicing the educational activities included in } \\
\text { the distance education system in teaching listening and speaking skills. }\end{array}$ & $(\% 95)$ \\
\hline 6 & $\begin{array}{l}\text { Taking into account the individual differences of students in teaching listening and } \\
\text { speaking skills. }\end{array}$ & $(\% 85)$ \\
\hline 7 & $\begin{array}{l}\text { Achieving comprehensive follow-up of learner behaviors in teaching listening and } \\
\text { speaking skills. }\end{array}$ & $(\% 90)$ \\
\hline 8 & $\begin{array}{l}\text { Providing the learner with positive, new and interactive behaviors in teaching } \\
\text { listening and speaking skills. }\end{array}$ & $(\% 100)$ \\
\hline 9 & $\begin{array}{l}\text { Providing the teacher and the learner with solutions and alternatives to quickly } \\
\text { solve problems in teaching listening and speaking skills. }\end{array}$ & $(\% 90)$ \\
\hline 10 & $\begin{array}{l}\text { Psychological satisfaction and happiness with the application of the distance } \\
\text { education system. }\end{array}$ & $(\% 85)$ \\
\hline 11 & $\begin{array}{l}\text { Diversifying teaching methods by the teacher during the application of the } \\
\text { distance education system. }\end{array}$ & $(\% 90)$ \\
\hline 12 & $\begin{array}{l}\text { Activating modern strategies in the distance education system on the part of the } \\
\text { teacher. }\end{array}$ & $(\% 90)$ \\
\hline 13 & Adherence to the procedures of each strategy separately on the part of the learner. & $(\% 90)$ \\
\hline 14 & $\begin{array}{l}\text { Activating the activities and events in the distance education system by the } \\
\text { teacher. }\end{array}$ & $(\% 90)$ \\
\hline 15 & $\begin{array}{l}\text { Commitment to teaching procedures while applying the distance education } \\
\text { system. }\end{array}$ & $(\% 100)$ \\
\hline \multicolumn{3}{|c|}{ Second - technical technological standards, which include: } \\
\hline 16 & $\begin{array}{l}\text { Diversifying the programs used in the distance education system to teach listening } \\
\text { and speaking skills. }\end{array}$ & $(\% 85)$ \\
\hline 17 & $\begin{array}{l}\text { Provide technical and technical support to students and teachers in teaching } \\
\text { listening and speaking skills. }\end{array}$ & $(\% 90)$ \\
\hline 18 & Providing scientific books and e-courses in teaching listening and speaking skills. & $(\% 90)$ \\
\hline 19 & $\begin{array}{l}\text { Using educational aids such as pictures, drawings and videos while applying the } \\
\text { distance education system in teaching listening and speaking skills. }\end{array}$ & $(\% 90)$ \\
\hline 20 & $\begin{array}{l}\text { The availability of modern communication mechanisms, including computers and } \\
\text { networks, in teaching listening and speaking skills. }\end{array}$ & $(\% 100)$ \\
\hline 21 & $\begin{array}{l}\text { The use of computer and electronic applications in the teaching and learning } \\
\text { process in teaching listening and speaking skills. }\end{array}$ & $(\% 90)$ \\
\hline 22 & Update electronic information content in teaching listening and speaking skills. & $(\% 85)$ \\
\hline 23 & $\begin{array}{l}\text { Multiple sources of knowledge and dealing with thousands of websites in teaching } \\
\text { listening and speaking skills. }\end{array}$ & $(\% 90)$ \\
\hline 24 & $\begin{array}{l}\text { Developing the personality of the learner in the distance education system in } \\
\text { teaching listening and speaking skills. }\end{array}$ & $(\% 85)$ \\
\hline 25 & $\begin{array}{l}\text { Improving the quality of teaching and learning during the study and research } \\
\text { process. }\end{array}$ & $(\% 90)$ \\
\hline 26 & $\begin{array}{l}\text { Achieving mental and behavioral flexibility on the part of the learner and teacher } \\
\text { in order to save time and effort in the study and research process. }\end{array}$ & $(\% 100)$ \\
\hline 27 & Modeling and presenting education in a standardized format. & $(\% 90)$ \\
\hline 28 & Motivating students to self-learning through interaction and reading. & $(\% 85)$ \\
\hline
\end{tabular}




\begin{tabular}{|c|c|c|}
\hline 29 & $\begin{array}{l}\text { Providing students with knowledge, information and skills with the least time and } \\
\text { effort in teaching listening and speaking skills. }\end{array}$ & $(\% 90)$ \\
\hline 30 & Modeling and standardizing education in teaching listening and speaking skills. & $(\% 85)$ \\
\hline \multicolumn{3}{|c|}{ Third - professional / scientific standards, which include: } \\
\hline 31 & $\begin{array}{l}\text { Enabling the teacher to develop the scientific and academic level of the learner in } \\
\text { teaching listening and speaking skills. }\end{array}$ & $(\% 100)$ \\
\hline 32 & $\begin{array}{l}\text { Providing the learner with new and advanced experiences through the distance } \\
\text { education system in teaching listening and speaking skills. }\end{array}$ & $(\% 90)$ \\
\hline 33 & $\begin{array}{l}\text { Effectively employing the experiences of the learner during the application of the } \\
\text { distance education system. }\end{array}$ & $(\% 90)$ \\
\hline 34 & $\begin{array}{l}\text { Empowering students with oral and written expression in teaching listening and } \\
\text { speaking skills. }\end{array}$ & $(\% 85)$ \\
\hline 35 & $\begin{array}{l}\text { Providing students with the main values included in the scientific material in } \\
\text { teaching listening and speaking skills. }\end{array}$ & $(\% 90)$ \\
\hline 36 & $\begin{array}{l}\text { Achieving comprehensive quality in providing scientific knowledge in teaching } \\
\text { listening and speaking skills. }\end{array}$ & $(\% 85)$ \\
\hline 37 & $\begin{array}{l}\text { Achieving systematic and periodic review of the teacher and the learner in } \\
\text { teaching listening and speaking skills. }\end{array}$ & $(\% 90)$ \\
\hline 38 & $\begin{array}{l}\text { Provide feedback during the study and research process in teaching listening and } \\
\text { speaking skills. }\end{array}$ & $(\% 100)$ \\
\hline 39 & $\begin{array}{l}\text { Satisfying the basic needs of the teacher and the learner in teaching listening and } \\
\text { speaking skills. }\end{array}$ & $(\% 90)$ \\
\hline 40 & $\begin{array}{l}\text { Clarity of the educational goals of the teacher and the learner in teaching listening } \\
\text { and speaking skills. }\end{array}$ & $(\% 85)$ \\
\hline 41 & $\begin{array}{l}\text { Clarity of measurement and evaluation tools for the teacher and the learner in } \\
\text { teaching listening and speaking skills. }\end{array}$ & $(\% 90)$ \\
\hline 42 & $\begin{array}{l}\text { Taking into account the basic needs of educational institutions in teaching } \\
\text { listening and speaking skills. }\end{array}$ & $(\% 90)$ \\
\hline 43 & $\begin{array}{l}\text { Diversifying questions presented to students during the application of the distance } \\
\text { education system in teaching listening and speaking skills. }\end{array}$ & $(\% 100)$ \\
\hline 44 & $\begin{array}{l}\text { Diversifying experiences and skills provided during the application of the distance } \\
\text { education system in teaching listening and speaking skills. }\end{array}$ & $(\% 90)$ \\
\hline 45 & $\begin{array}{l}\text { Ensuring follow-up, focus and questioning by the teacher and the learner in } \\
\text { teaching listening and speaking skills. }\end{array}$ & $(\% 85)$ \\
\hline
\end{tabular}

\section{2- Results related to the second question from the research questions:}

The text of the second question reads as follows: What are the availability of standards in educational practices for both the teacher and the learner in teaching listening and speaking skills?

Table No. (2) shows the availability of standards in educational practices for both the teacher and the learner in teaching listening and speaking skills

\begin{tabular}{|c|c|c|c|c|c|c|c|c|c|c|}
\hline \multirow[t]{2}{*}{ SN } & \multirow[t]{3}{*}{$\begin{array}{l}\text { Distance education system quality standards } \\
\text { in teaching listening and speaking skills }\end{array}$} & \multicolumn{9}{|c|}{$\begin{array}{l}\text { The extent of its availability in educational practices for both the teacher and the learner in } \\
\text { teaching listening and speaking skills }\end{array}$} \\
\hline & & \multicolumn{3}{|c|}{$\begin{array}{l}\text { The first grade includes these } \\
\text { criteria with a degree }\end{array}$} & \multicolumn{3}{|c|}{$\begin{array}{l}\text { The second grade includes } \\
\text { these criteria with a degree }\end{array}$} & \multicolumn{3}{|c|}{$\begin{array}{l}\text { The third grade includes } \\
\text { these criteria with a degree }\end{array}$} \\
\hline First - educational standards, which include: & & Large & medium & Weak & Large & medium & weak & Large & medium & weak \\
\hline 1 & $\begin{array}{l}\text { Distance education achieves positive } \\
\text { interaction with knowledge and information in } \\
\text { teaching listening and speaking skills. }\end{array}$ & 1 & & & 1 & & & 1 & & \\
\hline 2 & $\begin{array}{l}\text { Distance education enables the teacher to } \\
\text { achieve his educational goals in teaching } \\
\text { listening and speaking skills. }\end{array}$ & & 1 & & 1 & & & 1 & & \\
\hline 3 & $\begin{array}{l}\text { Students interact positively with the teacher } \\
\text { and subject in teaching listening and speaking } \\
\text { skills. }\end{array}$ & & 1 & & 1 & & & 1 & & \\
\hline 4 & $\begin{array}{l}\text { Taking into account the cultural and linguistic } \\
\text { side of the teacher and the learner in teaching } \\
\text { listening and speaking skills. }\end{array}$ & 1 & & & 1 & & & 1 & & \\
\hline 5 & $\begin{array}{l}\text { The effectiveness of students in practicing the } \\
\text { educational activities included in the distance } \\
\text { education system in teaching listening and } \\
\text { speaking skills. }\end{array}$ & 1 & & & 1 & & & 1 & & \\
\hline 6 & $\begin{array}{l}\text { Taking into account the individual differences } \\
\text { of students in teaching listening and speaking } \\
\text { skills. }\end{array}$ & 1 & & & 1 & & & 1 & & \\
\hline 7 & $\begin{array}{l}\text { Achieving comprehensive follow-up of learner } \\
\text { behaviors in teaching listening and speaking } \\
\text { skills. }\end{array}$ & 1 & & & 1 & & & 1 & & \\
\hline
\end{tabular}




\begin{tabular}{|c|c|c|c|c|c|c|c|c|c|c|}
\hline 8 & $\begin{array}{l}\text { Providing the learner with positive, new and } \\
\text { interactive behaviors in teaching listening and } \\
\text { speaking skills. }\end{array}$ & 1 & & & 1 & & & 1 & & \\
\hline 9 & $\begin{array}{l}\text { Providing the teacher and the learner with } \\
\text { solutions and alternatives to quickly solve } \\
\text { problems in teaching listening and speaking } \\
\text { skills. }\end{array}$ & 1 & & & 1 & & & & 1 & \\
\hline 10 & $\begin{array}{l}\text { Psychological satisfaction and happiness with } \\
\text { the application of the distance education } \\
\text { system. }\end{array}$ & 1 & & & 1 & & & & 1 & \\
\hline 11 & $\begin{array}{l}\text { Diversifying teaching methods by the teacher } \\
\text { during the application of the distance education } \\
\text { system. }\end{array}$ & & & 1 & & & 1 & & & 1 \\
\hline 12 & $\begin{array}{l}\text { Activating modern strategies in the distance } \\
\text { education system on the part of the teacher. }\end{array}$ & 1 & & & & 1 & & & 1 & \\
\hline 13 & $\begin{array}{l}\text { Adherence to the procedures of each strategy } \\
\text { separately on the part of the learner. }\end{array}$ & & & 1 & & 1 & & & 1 & \\
\hline 14 & $\begin{array}{l}\text { Activating the activities and events in the } \\
\text { distance education system by the teacher. }\end{array}$ & & 1 & & & 1 & & & 1 & \\
\hline 15 & $\begin{array}{l}\text { Commitment to teaching procedures while } \\
\text { applying the distance education system. }\end{array}$ & & 1 & & & 1 & & & 1 & \\
\hline \multicolumn{2}{|c|}{ Total } & 9 & 4 & 2 & 10 & 4 & 1 & 8 & 6 & 1 \\
\hline \multirow{2}{*}{\multicolumn{2}{|c|}{$\begin{array}{l}\text { Percentage } \\
\text { Second - technical technological standards, which } \\
\text { include: }\end{array}$}} & $\%$ & $\% 27$ & $\% 13$ & $\% 66$ & $\% 27$ & $\% 7$ & $\% 53$ & $\% 40$ & $\% 7$ \\
\hline & & & & & & & & & & \\
\hline 16 & $\begin{array}{l}\text { Diversifying the programs used in the distance } \\
\text { education system to teach listening and } \\
\text { speaking skills. }\end{array}$ & 1 & & & & 1 & & & 1 & \\
\hline 17 & $\begin{array}{l}\text { Provide technical and technical support to } \\
\text { students and teachers in teaching listening and } \\
\text { speaking skills. }\end{array}$ & 1 & & & 1 & & & 1 & & \\
\hline 18 & $\begin{array}{l}\text { Providing scientific books and e-courses in } \\
\text { teaching listening and speaking skills. }\end{array}$ & 1 & & & 1 & & & 1 & & \\
\hline 19 & $\begin{array}{l}\text { Using educational aids such as pictures, } \\
\text { drawings and videos while applying the } \\
\text { distance education system in teaching listening } \\
\text { and speaking skills. }\end{array}$ & & 1 & & & 1 & & & 1 & \\
\hline 20 & $\begin{array}{l}\text { The availability of modern communication } \\
\text { mechanisms, including computers and } \\
\text { networks, in teaching listening and speaking } \\
\text { skills. }\end{array}$ & 1 & & & 1 & & & 1 & & \\
\hline 21 & $\begin{array}{l}\text { The use of computer and electronic } \\
\text { applications in the teaching and learning } \\
\text { process in teaching listening and speaking } \\
\text { skills. }\end{array}$ & 1 & & & 1 & & & 1 & & \\
\hline 22 & $\begin{array}{l}\text { Update electronic information content in } \\
\text { teaching listening and speaking skills. }\end{array}$ & 1 & & & & 1 & & & 1 & \\
\hline 23 & $\begin{array}{l}\text { Multiple sources of knowledge and dealing } \\
\text { with thousands of websites in teaching } \\
\text { listening and speaking skills. }\end{array}$ & & & 1 & & & 1 & & & 1 \\
\hline 24 & $\begin{array}{l}\text { Developing the personality of the learner in the } \\
\text { distance education system in teaching listening } \\
\text { and speaking skills. }\end{array}$ & 1 & & & & 1 & & & 1 & \\
\hline 25 & $\begin{array}{l}\text { Improving the quality of teaching and learning } \\
\text { during the study and research process. }\end{array}$ & & 1 & & & 1 & & & 1 & \\
\hline 26 & $\begin{array}{l}\text { Achieving mental and behavioral flexibility on } \\
\text { the part of the learner and teacher in order to } \\
\text { save time and effort in the study and research } \\
\text { process. }\end{array}$ & & 1 & & & 1 & & & 1 & \\
\hline 27 & $\begin{array}{l}\text { Modeling and presenting education in a } \\
\text { standardized format. }\end{array}$ & & & 1 & & & 1 & & & 1 \\
\hline 28 & $\begin{array}{l}\text { Motivating students to self-learning through } \\
\text { interaction and reading. }\end{array}$ & & & 1 & & & 1 & & & 1 \\
\hline 29 & $\begin{array}{l}\text { Providing students with knowledge, } \\
\text { information and skills with the least time and } \\
\text { effort in teaching listening and speaking skills. }\end{array}$ & 1 & & & & 1 & & & 1 & \\
\hline 30 & $\begin{array}{l}\text { Modeling and standardizing education in } \\
\text { teaching listening and speaking skills. }\end{array}$ & & & 1 & & & 1 & & & 1 \\
\hline \multicolumn{2}{|r|}{ 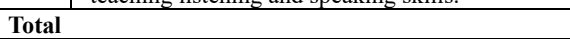 } & 8 & 3 & 4 & 4 & 7 & 4 & 4 & 7 & 4 \\
\hline \multicolumn{2}{|c|}{ Percentage } & $\% 53$ & $\% 20$ & $\% 27$ & $\% 27$ & $\% 46$ & $\% 27$ & $\% 27$ & $\% 46$ & $\% 27$ \\
\hline \multicolumn{11}{|c|}{$\begin{array}{l}\text { Third - professional / scientific standards, which } \\
\text { include: }\end{array}$} \\
\hline 31 & $\begin{array}{l}\text { Enabling the teacher to develop the scientific } \\
\text { and academic level of the learner in teaching } \\
\text { listening and speaking skills. }\end{array}$ & 1 & & & & 1 & & & 1 & \\
\hline 32 & $\begin{array}{l}\text { Providing the learner with new and advanced } \\
\text { experiences through the distance education } \\
\text { system in teaching listening and speaking } \\
\text { skills. }\end{array}$ & 1 & & & & 1 & & & 1 & \\
\hline 33 & $\begin{array}{l}\text { Effectively employing the experiences of the } \\
\text { learner during the application of the distance } \\
\text { education system. }\end{array}$ & 1 & & & & 1 & & & 1 & \\
\hline
\end{tabular}




\begin{tabular}{|c|c|c|c|c|c|c|c|c|c|c|}
\hline 34 & $\begin{array}{l}\text { Empowering students with oral and written } \\
\text { expression in teaching listening and speaking } \\
\text { skills. }\end{array}$ & 1 & & & 1 & & & 1 & & \\
\hline 35 & $\begin{array}{l}\text { Providing students with the main values } \\
\text { included in the scientific material in teaching } \\
\text { listening and speaking skills. }\end{array}$ & 1 & & & & 1 & & & 1 & \\
\hline 36 & $\begin{array}{l}\text { Achieving comprehensive quality in providing } \\
\text { scientific knowledge in teaching listening and } \\
\text { speaking skills. }\end{array}$ & & 1 & & & 1 & & & 1 & \\
\hline 37 & $\begin{array}{l}\text { Achieving systematic and periodic review of } \\
\text { the teacher and the learner in teaching listening } \\
\text { and speaking skills. }\end{array}$ & & 1 & & & 1 & & & 1 & \\
\hline 38 & $\begin{array}{l}\text { Provide feedback during the study and research } \\
\text { process in teaching listening and speaking } \\
\text { skills. }\end{array}$ & & & 1 & & & 1 & & & 1 \\
\hline 39 & $\begin{array}{l}\text { Satisfying the basic needs of the teacher and } \\
\text { the learner in teaching listening and speaking } \\
\text { skills. }\end{array}$ & & 1 & & & 1 & & & 1 & \\
\hline 40 & $\begin{array}{l}\text { The clarity of the educational goals of the } \\
\text { teacher and the learner in teaching listening and } \\
\text { speaking skills. }\end{array}$ & 1 & & & 1 & & & 1 & & \\
\hline 41 & $\begin{array}{l}\text { Clarity of measurement and evaluation tools } \\
\text { for the teacher and the learner in teaching } \\
\text { listening and speaking skills. }\end{array}$ & 1 & & & & & 1 & 1 & & \\
\hline 42 & $\begin{array}{l}\text { Taking into account the basic needs of } \\
\text { educational institutions in teaching listening } \\
\text { and speaking skills. }\end{array}$ & & 1 & & & 1 & & & 1 & \\
\hline 43 & $\begin{array}{l}\text { Diversifying questions presented to students } \\
\text { during the application of the distance education } \\
\text { system in teaching listening and speaking } \\
\text { skills. }\end{array}$ & & 1 & & & 1 & & & 1 & \\
\hline 44 & $\begin{array}{l}\text { Diversifying experiences and skills provided } \\
\text { during the application of the distance education } \\
\text { system in teaching listening and speaking } \\
\text { skills. }\end{array}$ & & 1 & & & 1 & & & 1 & \\
\hline 45 & $\begin{array}{l}\text { Ensuring follow-up, focus and questioning by } \\
\text { the teacher and the learner in teaching listening } \\
\text { and speaking skills. }\end{array}$ & 1 & & & 1 & & & 1 & & \\
\hline \multicolumn{2}{|r|}{ on } & 8 & 6 & 1 & 3 & 10 & 2 & 4 & 10 & 1 \\
\hline \multicolumn{2}{|c|}{ Percentage } & $\% 53$ & $\% 40$ & $\% 7$ & $\% 20$ & $\% 66$ & $\% 14$ & $\% 27$ & $\% 66$ & $\% 7$ \\
\hline
\end{tabular}

Table No. (3) shows the percentage and general level of the availability of standards in educational practices for both the teacher and the learner in teaching listening and speaking skills

\begin{tabular}{|c|c|c|c|c|c|}
\hline \multirow[t]{2}{*}{ Class } & \multirow[t]{2}{*}{ Standards } & \multicolumn{3}{|c|}{$\begin{array}{c}\text { Percentage of standards availability by } \\
\text { degree }\end{array}$} & \multirow[t]{2}{*}{ General level } \\
\hline & & High & Medium & Weak & \\
\hline \multirow[t]{3}{*}{ The first primary } & Educational & $\% 13$ & $\% 27$ & $\% 60$ & High \\
\hline & $\begin{array}{r}\text { Technical } \\
\text { technology }\end{array}$ & $\% 27$ & $\% 20$ & $\% 53$ & High \\
\hline & $\begin{array}{c}\text { Scientific } \\
\text { professional }\end{array}$ & $\% 7$ & $\% 40$ & $\% 53$ & High \\
\hline \multirow[t]{3}{*}{ The second primary } & Educational & $\% 7$ & $\% 27$ & $\% 66$ & High \\
\hline & $\begin{array}{l}\text { Technical } \\
\text { technology }\end{array}$ & $\% 27$ & $\% 46$ & $\% 27$ & medium \\
\hline & $\begin{array}{c}\text { Scientific } \\
\text { professional }\end{array}$ & $\% 14$ & $\% 66$ & $\% 20$ & medium \\
\hline \multirow[t]{3}{*}{ Third primary } & Educational & $\% 7$ & $\% 40$ & $\% 53$ & High \\
\hline & $\begin{array}{l}\text { Technical } \\
\text { technology }\end{array}$ & $\% 27$ & $\% 46$ & $\% 27$ & medium \\
\hline & $\begin{array}{c}\text { Scientific } \\
\text { professional }\end{array}$ & $\% 7$ & $\% 66$ & $\% 27$ & medium \\
\hline
\end{tabular}

\section{3- Results related to the third question from the research questions:}

The third question stipulated the following: What are the necessary procedures that enable teachers and students to acquire these standards in teaching listening and speaking skills? Where the researcher prepared a list of necessary procedures that enable teachers and students to acquire these standards in teaching listening and speaking skills in Appendix No. (2) Thus, the researcher reached the answer to the third question of the research questions. 


\section{Research Recommendations and Suggestions:}

1- Research Recommendations:

A- Designing training programs for teachers and students on the importance of distance education.

B - Holding training courses for teachers and educational supervisors to provide them with the necessary standards for the quality of distance education.

C - Developing methods for evaluating students' performance while listening and speaking, so that these methods include listening and speaking skills.

D - Make use of the list of quality standards for distance education by teachers, supervisors, and those interested in developing listening and speaking skills in the general education stages.

E- Activating and using the procedures proposed in the research; To provide students with listening and speaking skills.

\section{Research proposals:}

A- Conducting research that determines the skills necessary for listening and speaking for middle school students. B- Conducting research that determines the listening and speaking skills of university education students.

$\mathrm{C}$ - Conducting research that identifies the reasons for the low level of students in the general education stages in terms of listening and speaking skills.

D - Conducting research to determine the extent to which high school students have the skills of listening and speaking.

\section{List of references:}

Aarssen, L. W., \& Crimi, L. (2016). Legacy, leisure and the 'work hard-Play hard' hypothesis. The Open Psychology Journal, 9. Retrieved from aarssenl@queensu.ca, Abdollahi, A. (2013). Political psychology of the death terror. In S. J. Sinclair, D. Antonius, S. J. Sinclair (Ed), \& D. Antonius (Ed) (Eds.), T. political psychology of terrorism fears. (pp. 213-226). https://doi. org/10. 1093/acprof:oso/9780199925926. 003. 001., Abdollahi, A., Pyszczynski, T., Maxfield, M., \& Luszczynska, A. (2011). Posttraumatic stress reactions as a disruption in anxiety-buffer functioning: Dissociation and responses to mortality salience as predictors of severity of posttraumatic symptoms. Psy, 329-341. Retrieved from tpyszczy@uccs.edu, Abel, E. L., \& Kruger, M. L. (2009). Mortality salience of birthdays on day of death in the major leagues. Death Studies, 33(2), 175-184. Retrieved from eabel@wayne.edu, Abeyta, A. A., Juhl, J., \& Routledge, C. (2014). Exploring the effects of self-esteem and mortality salience on proximal and distally measured death anxiety: A further test of the dual process model of terror management. Motivation and Emotion, 38(4), 523-528. Retrieved from andrew.abeyta@my.ndsu.edu, Abeyta, A. A., Nelson, T. A., \& Routledge, C. (2019). Precious time: The role of time and temporal thought in managing death awareness. In C. Routledge \& M. Vess (Eds.), H. of terror management theory. (pp. 209-225). https://doi. org/10. 1016/B97.-0-12-811844-3. 0000.-1, Abrams, D. (2004). The development of social identity: What develops? In M. Bennett, F. Sani, M. Bennett (Ed), \& F. Sani (Ed) (Eds.), T. development of the social self. (pp. 291-312). https://doi. org/10. 4324/9780203391099_chapter_1., Adams, C. B. L. (2012). Beyond attachment: Psychotherapy with a sexually abused teenager. American Journal of Psychotherapy, 66(4), 313-330. Retrieved from CBLAdams@bellsouth.net, Agroskin, D., \& Jonas, E. (2013). Controlling death by defending ingroups-Mediational insights into terror management and control restoration. Journal of Experimental Social Psychology, 49(6), 1144-1158. Retrieved from dmitrij.agroskin@sbg.ac.at, Agroskin, D., \& Jonas, E. (2014). Erratum to "Controlling death by defending ingroups-Mediational insights into terror management and control restoration". Journal of Experimental Social Psychology, 52, 24. Retrieved from dmitrij.agroskin@sbg.ac.at, Agroskin, D., Jonas, E., Klackl, J., \& Prentice, M. (2016). Inhibition underlies the effect of high need for closure on cultural closed-mindedness under mortality salience. Frontiers in Psychology, 7. Retrieved from mptg2@mail.missouri.edu, Agustin, A. A., \& Francisco, V. G. J. (2008). Analysing the effects of mortality salience on prejudice and decision-taking. New Developments in the Psychology of Motivation, 53-65., Agustin, E.-E. (2009). Effects of mortality salience aroused by threats against human identity on intergroup bias. European Journal of Social Psychology, 39(5), 862-867. Retrieved from pspeteta@ss.ehu.es, Ai, A. L., Kastenmüller, A., Tice, T. N., Wink, P., Dillon, M., \& Frey, D. (2014). The Connection of Soul (COS) scale: An assessment tool for afterlife perspectives in different worldviews. Psychology of Religion and Spirituality, 6(4), 316-329. Retrieved from amyai8@gmail.com, Allen, M. W., \& Wilson, M. (2005). Materialism and food security. Appetite, 45(3), 314-323. Retrieved from m.allen@econ.usyd.edu.au, Alper, S., \& Özkan, T. (2015). Do internals speed less and externals speed more to cope with the death anxiety? Transportation Research Part F: Traffic Psychology and Behaviour, 32, 68-77. Retrieved from sinan.alper@metu.edu.tr, Amiot, C. E., Sukhanova, K., Greenaway, K. H., \& Bastian, B. (2017). Does human-animal similarity lower the need to affirm humans' superiority relative to animals? A social psychological viewpoint. Anthrozoös, 30(3), 499-516. Retrieved from 
amiot.catherine@uqam.ca, An, E., Lo, C., Hales, S., Zimmermann, C., \& Rodin, G. (2018). D. and death anxiety in advanced cancer. P.-O. https://doi. org/10. 1002/pon. 484., Anaki, D., Brezniak, T., \& Shalom, L. (2012). Faces in the face of death: Effects of exposure to life-threatening events and mortality salience on facial expression recognition in combat and noncombat military veterans. Emotion, 12(4), 860-867. Retrieved from david.anaki@biu.ac.il,... Goldenberg, J. L., Pyszczynski, T., Greenberg, J., Solomon, S., Kluck, B., \& Cornwell, R. (2001). I am not an animal: mortality salience, disgust, and the denial of human creatureliness. Journal of Experimental Psychology. General, 130(3), 427-435. Retrieved from http://www.ncbi.nlm.nih.gov/pubmed/11561918. (2000). The impact of imagining partner loss and mortality salience on romantic relationship satisfaction. In Dissertation Abstracts International: Section B: The Sciences and Engineering.

Boud, D., Keogh, R., Walker, D., Reinhart, C., Wyatt, T., Vygotsky, L., Dewey, J., Young, M. G., Malisius, E., \& Dueck, P., Utech, J. L., Maghuyop, A. Z., Sebastien, B., Team, T. E., Education, D. of, Furco, A., Innotech, Perin, D., Hare, R., Piaget, J., Zeidenberg, M., ... Dewy, J. (2016). Curriculum development in vocational and technical education: Planning, content, and implementation. Brooklyn, NY:Workforce Strategy Center.

Deye, N., Vincent, F., Michel, P., Ehrmann, S., Da Silva, D., Piagnerelli, M., ... Laterre, P.-F. (2016). Changes in cardiac arrest patientsâ€TM temperature management after the 2013 â€œTTMâ€ trial: Results from an international survey. Annals of Intensive, 6(1). http://doi.org/10.1186/s13613-015-0104-6, Al-Hussaini, M., \& Mustafa, S. (2016). Adolescentsâ€TM knowledge and awareness of diabetes mellitus in Kuwait. Alexandria Journal of Medicine, 52(1), 61-66. http://doi.org/10.1016/j.ajme.2015.04.001, Pollach, G., Brunkhorst, F., Mipando, M., Namboya, F., Mndolo, S., \& Luiz, T. (2016). The â€œfirst digit lawâ€ â€" A hypothesis on its possible impact on medicine and development aid. Medical Hypotheses, 97, 102106. http://doi.org/10.1016/j.mehy.2016.10.021, Asiedu, K., Kyei, S., Ayobi, B., Agyemang, F. O., \& Ablordeppey, R. K. (2016). Survey of eye practitionersâ€TM preference of diagnostic tests and treatment modalities for dry eye in Ghana. Contact Lens Anterior Eye, 39(6), 411-415. http://doi.org/10.1016/j.clae.2016.08.001, Barakat, K. H., Gajewski, M. M., \& Tuszynski, J. A. (2012). DNA polymerase beta (pol $\beta$ ) inhibitors: A comprehensive overview. Drug Discovery Today, 17(15-16), 913-920. http://doi.org/10.1016/j.drudis.2012.04.008, Mocan, O., \& Dumitraşcu, D. L. (2016). The broad spectrum of celiac disease and gluten sensitive enteropathy. Clujul Medical, 89(3), 335-342. http://doi.org/10.15386/cjmed-698, Kuoe, K., Wioeniewska, A., Totoñ-Zurañska, J., Gajda, M., Jawieñ, J., Olszanecki, R., \& Korbut, R. (2013). Antiatherogenic effect of nebivolol-the third generation $\beta$-blocker. $\begin{array}{lllll}\text { Pharmacological } & \text { Reports, } & 65, & 61 . & \text { Retrieved }\end{array}$ http://www.embase.com/search/results?subaction=viewrecord\&from=export\&id=L 71688280, Hamed, R. B., Gomez-Castellanos, J. R., Henry, L., Ducho, C., McDonough, M. A., \& Schofield, C. J. (2013). The enzymes of $\beta$-lactam biosynthesis. Natural Product Reports, 30(1), 21-107. http://doi.org/10.1039/c2np20065a, Li, G.-R., Chen, K.-H., \& Sun, H.-Y. (2013). Distinctive density, biophysical properties, and pharmacology of voltage-gated sodium current in atrial and ventricular myocytes. Heart Rhythm, 10(5), S. R. from http://www. embase. com/search/results?subaction=viewrecord\&from=export\&id=L7106721., Farag, M. A. (2014). Comparative mass spectrometry \& nuclear magnetic resonance metabolomic approaches for nutraceuticals quality control analysis: A brief review. Recent Patents on Biotechnology, 8(1), 17-24. http://doi.org/10.2174/1389201014666131218125035, Singh, H., Mishra, A., \& Mishra, A. K. (2015). Cleome viscosa Linn (Capparaceae): A review. Pharmacognosy Journal, 7(6), 326-329. http://doi.org/10.5530/pj.2015.6.1, Rani, C., \& Khan, I. A. (2016). UDP-GlcNAc pathway: Potential target for inhibitor discovery against M. tuberculosis. European Journal of Pharmaceutical Sciences, 83, 62-70. http://doi.org/10.1016/j.ejps.2015.12.013, Kratz, F., Azab, S. S. E. E. A., Zeisig, R., Fichtner, I., \& Warnecke, A. (2012). Combination therapy of doxorubicin and the acid-sensitive albumin-binding prodrug of doxorubicin INNO-206 induces complete regressions in a xenograft pancreatic carcinoma mo, 72(8). http://doi.org/10.1158/1538-7445.AM2012-2756, Ngo, L. T., Okogun, J. I., \& Folk, W. R. (2013). 21st Century natural product research and drug development and traditional medicines. Natural Product Reports, 30(4), 584-592. http://doi.org/10.1039/c3np20120a, Lazarski, C. A., Brough, D. E., \& Wei, L. L. (2013). Novel adenoviral vectors induce robust $t$ cell responses to HSV2 and significantly boost responses after repeat homologous administration. Molecular Therapy, 21(9), e37. http://doi. org/10. 1038/mt. 2013. 14., Abdallah, M. A. E., Pawar, G., \& Harrad, S. (2015). Evaluation of in vitro vs. in vivo methods for assessment of dermal absorption of organic flame retardants: A review. Environment International, 74, 1322. http://doi.org/10.1016/j.envint.2014.09.012, Doggrell, S., Warot, S., \& Chan, V. (2014). Ongoing poor management of medicines in the older-aged living independently in a rental retirement village. Basic and Clinical Pharmacology and Toxicology, 115, 78. Retrieved from http://www.embase.com/search/results?subaction=viewrecord\&from=export\&id=L71549254, Tayeb, H. 
T., Bakheet, D. H., Ajlan, A., Al-Jedai, A., Zaza, K., \& Dzimiri, N. (2014). Genotyping of CYP2C19 polymorphisms and its potential clinical application in the saudi population. Basic and Clinical Pharmacology and Toxicology, 115, 163. Retrieved from http://www.embase.com/search/results?subaction=viewrecord\&from=export\&id=L71549538, Muiya, N. P., Wakil, S. M., Nguen, C., Andres, E., Baz, B., Morahan, G., ... Dzimiri, N. (2014). Determination of pgeni gene variants by DMET chip in the Saudi population. Basic and Clinical Pharmacology and

Toxicology, $115, \quad 65 . \quad$ Retrieved from http://www.embase.com/search/results?subaction=viewrecord\&from=export\&id=L71549212, Chinsembu, K. C. (2015). Plants as antimalarial agents in Sub-Saharan Africa. Acta Tropica, 152, 32-48. http://doi.org/10.1016/j.actatropica.2015.08.009. (2016). Osteonecrosis in children with acute lymphoblastic leukemia: A report from children's cancer hospital in Egypt (CCHE). Pediatric Blood and Cancer.

Mathew, R. V., \& Panchanatham, N. 2016. An exploratory study on the development of women entrepreneurs: Indian cases. Journal of Research in Marketing and Entrepreneurship, 18(2): 232-247., Chowdhry, G., \& Beeman, M. 2001. Transnational Activism and India's Carpet Industry. Annals, 158-175., Van Velsor, E., Wilson, M., Criswell, C., \& Chandrasekar, N. A. 2013. Learning to lead: A comparison of developmental events and learning among managers in China, India and the United States. Asian Business and Management, 12(4): 455-476., Poster, W. R. 2011. Emotion detectors, answering machines, and e-unions: Multi- surveillances in the global interactive service industry. American Behavioral Scientist, 55(7): 868901., Singh, G. K., \& Kposowa, A. J. 2004. Occupation-specific earnings attainment of Asian Indians and whites in the United States: gender and nativity differentials across class strata. Applied Behavioral Science Review, 4(2): 137-175., Niranjan, T. T., \& Srivastava, S. K. 2008. Managing Capacity at Sparsh Call Centre. Asian Case Research Journal, 12(01): 73-103., Gupta, M., \& Shukla, K. 2018. An Empirical Clarification on the Assessment of Engagement at Work. Advances in Developing Human Resources, 20(1): 44-57., Chaudhuri, S., Hirudayaraj, M., \& Ardichvili, A. 2018. Borrow or Grow: An Overview of Talent Development/Management Practices in Indian IT Organizations. Advances in Developing Human Resources, 20(4): 460-478., Shaheen, M., Zeba, F., \& Mohanty, P. K. 2018. Can Engaged and Positive Employees Delight Customers? Advances in Developing Human Resources, 20(1): 103-122., Gupta, M. 2018. Engaging Employees at Work: Insights From India. Advances in Developing Human Resources, 20(1): 3-10., Ghosh, R. 2016. Gender and Diversity in India: Contested Territories for HRD? Advances in Developing Human Resources, 18(1): 3-10., Wang, J. 2012. HRD for Societal Development: What Can We Learn From Social Entrepreneurship in the Developing World? Advances in Developing Human Resources, 14(3): 305-317., Rao, T. V. 2004. Human Resource Development as National Policy in India. Advances in Developing Human Resources, 6(3): 288-296., Garg, K., Dar, I. A., \& Mishra, M. 2018. Job Satisfaction and Work Engagement: A Study Using Private Sector Bank Managers. Advances in Developing Human Resources, 20(1): 58-71., Haynes, R., \& Alagaraja, M. 2016. On the Discourse of Affirmative Action and Reservation in the United States and India: Clarifying HRD's Role in Fostering Global Diversity. Advances in Developing Human Resources, 18(1): 69-87., Singh, S., David, R., \& Mikkilineni, S. 2018. Organizational Virtuousness and Work Engagement: Mediating Role of Happiness in India. Advances in Developing Human Resources, 20(1): 88-102., Dirani, K. M., \& Nafukho, F. M. 2018. Talent Management and Development: Perspectives From Emerging Market Economies. Advances in Developing Human Resources, 20(4): 383-388., Sekhar, C., Patwardhan, M., \& Vyas, V. 2018. Linking Work Engagement to Job Performance Through Flexible Human Resource Management. Advances in Developing Human Resources, 20(1): 72-87., Munn, S. L., \& Chaudhuri, S. 2016. Work-Life Balance: A Cross-Cultural Review of Dual-Earner Couples in India and the United States. Advances in Developing Human Resources, 18(1): 54-68., ... Walk, M., \& Handy, F. 2013. What do talents want ?, 27(3): 251-278. (2018). Enhancing Energy-based Livelihoods for Women Micro-entrepreneurs: A Case Study. ASCI Journal of Management.

Ojakaa, D., Day, W. H., Benard, R., Dulle, F., For, H., Degree, M., Acquah-swanzy, M., The Presidency of Ghana, Dicker, R. C., Adioetomo, S. R., Beninguisse, G., Gultiano, S., Hao, Y., Nacro, K., Pool, I., WHO, What, Q., Language, S. Q., Standards, A. N., ... United Nations. (2014). CSOs HSS support proposal. World Health Organization. 